\title{
Influence of Constituent Materials Properties on the Compressive Strength of in Situ Concrete in Kenya
}

\author{
Victoria Akoth Okumu1,2, Stanley Muse Shitote³, Walter Odhiambo Oyawa ${ }^{4}$ \\ ${ }^{1}$ Pan African University, Institute for Basic Sciences, Technology and Innovations (PAUISTI) Hosted at Jomo Kenyatta University \\ of Agriculture and Technology (JKUAT), Juja, Kenya \\ ${ }^{2}$ Multimedia University of Kenya, Nairobi, Kenya \\ ${ }^{3}$ Rongo University, Rongo, Kenya \\ ${ }^{4}$ Commission of University Education, Nairobi, Kenya \\ Email: vokumu@gmail.com,shitote@hotmail.com,oyawaw@yahoo.com
}

How to cite this paper: Okumu, V.A., Shitote, S.M. and Oyawa, W.O. (2017) Influence of Constituent Materials Properties on the Compressive Strength of in Situ Concrete in Kenya. Open Journal of Civil Engineering, 7, 63-81.

https://doi.org/10.4236/ojce.2017.71004

Received: December 1, 2016

Accepted: March 6, 2017

Published: March 9, 2017

Copyright $\odot 2017$ by authors and Scientific Research Publishing Inc. This work is licensed under the Creative Commons Attribution International License (CC BY 4.0).

http://creativecommons.org/licenses/by/4.0/

\begin{abstract}
The poor quality of Kenyan in situ concrete has necessitated research to establish the properties of the ingredient materials and their influence on the troubling rate of failure of reinforced concrete structures in the country during construction and usage. The compressive strength of concrete relies on the properties of the constituent materials, proportions of the mixture, workmanship, compaction method and curing conditions. This paper outlines findings of an experimental investigation on the properties of Kenyan concrete ingredient materials and their influence on the compressive strength of concrete in Kenya. Three types of cements (42.5N, 32.5R, 32.5N) from six different cement manufacturers and fine aggregates from three different regions in the country were used during the study. Cements and aggregates chemical analysis was done using the Atomic Absorption Spectrometer machine while the physical and the mechanical properties were checked based on the British Standards. The British DOE concrete mix design method was used to generate the concrete mix proportion and concrete was tested for early and ultimate compressive strengths at 7, 14 and 28 days. It was observed that the different cement brands have varying properties with CEM A having the highest ultimate compressive and flexural strengths. It was further noted that aggregates from the coastal region produced concrete of higher compressive strengths. When the commonly used mix design method was adopted, blended Portland cements produced concrete with ultimate compressive strengths lower than the designed target strengths. The study therefore recommends the development of a concrete mix design procedure for blended cement concrete production in Kenya.
\end{abstract}




\section{Keywords}

Blended Portland Cement, Ordinary Portland Cement, Concrete Compressive Strength, Concrete Constituent Materials, Blended Portland Cement Concrete

\section{Introduction}

Concrete is the most widely used construction materials worldwide with about 13 billion metric tons being used annually [1] [2] [3] [4]. This wide usage is attributed to its wide range of compressive strength, versatility, durability, low maintenance, fire-resistance, ease of local production and use [5] [6]. The production of concrete involves the mechanical and chemical interraction of its constituent materials; binder, fine and coarse aggregates and water thus the compressive strength, workability, durability and other properties of concrete rely on the individual properties of its constituent materials, mixture proportions, workmanship and curing conditions [2] [7] [8] [9]. The main factors influencing the concrete mix design are type and content of cement, water/cement ratio, aggregates ratio and total aggregate/cement ratio [10]. Approximately 31 reinforced concrete buildings have collapsed in Kenya between the years 2003 to 2015. Majority of the failure occurred during construction. This collapse has been attributed to among other possible causes, the quality of in-situ concrete and poor workmanship [2] [8] [11].

Research has shown that concrete compressive strength depends on the properties of cement used [2] [12]. The most commonly used cement in Kenya and most developing countries are the blended Portland cements [1]. The blended Portland cement concrete has lower compressive strengths at 28 days compared to Ordinary Portland cements concrete [2] [12] [13] [14] [15] [16]. The differences in the constituent materials also have an effect on the durability of concrete [17]. The reduction in strength is proportional to the type of and percentage of the pozzolanic material added to the blend [18]. Mouli et al. (2008) however report that the compressive, splitting and flexural strengths of the concrete can be improved in the long term by the addition of natural pozzolan between $20 \%-30 \%$ [19]. Khaled Marar and Özgür Eren also report that the workability of concrete can be improved by increasing cement content [20]. The variations in chemical constituents also affect the physical and mechanical properties of cement.

Aggregates constitute $70 \%$ to $80 \%$ of the total concrete volume [21]. In Kenya, the commonly used coarse aggregates are crushed stones while the commonly used fine aggregates are river sand. Research has also shown that the type, amount, composition, gradation and quality of aggregates affect the durability and compressive strength of concrete [5] [8] [21]-[28]. It has also been reported that the particle size distribution and fraction of coarse aggregates influence both the workability and strength properties of concrete [29]. Research by Amnon and Hadassa indicates that concrete compressive strength can be improved by up to 
$30 \%$ by addition of fines if workability can be controlled [30].

This study therefore evaluated the physical, chemical and mechanical properties of locally available cement, coarse aggregates and fine aggregates and investigated the influence of the cement and fine aggregates type and properties on the quality of in situ concrete in Kenya. In this paper, the properties of cement and aggregates are presented and their influence on the concrete compressive strength is evaluated.

\section{Methodology}

In concrete production, every constituent material is expected to perform certain specific functions to achieve the designed concrete compressive strength and other properties. The research experiments were divided into two parts: the first was to establish the chemical, physical and mechanical properties of the ingredient materials while the second was to investigate the effect of the properties of the cements and fine aggregates on the Kenyan concrete compressive strength.

\subsection{Materials}

\subsubsection{Cement}

In Kenya, Cement is produced in accordance to KS EAS 18-1: 2001 which is an adoption of the European Norm EN 197 cement standards [31]. Lime and natural pozzolanic materials such as tuffs, volcanic ashes and diatomaceous earths deposits are commonly used to manufacture the blended Portland cements. The cements locally available are Pozzolanic Cement (PC) CEM IV/A having 11\% $35 \%$ pozzolanic material, Portland Pozzolanic Cement (PPC) CEM II/B-P containing 21\% - 35\% natural pozzolana, Portland Limestone Cement (PLC) CEM II/A-LL having 6\% - 20\% limestone and Ordinary Portland cement (OPC) CEM I produced for specific uses [1]. Three types of cements $(42.5 \mathrm{~N}, 32.5 \mathrm{~N}$ and 32.5R) from six local manufacturers (CEM A, CEM B, CEM C, CEM D, CEM E, CEM F) were used during the research.

\subsubsection{Fine Aggregates}

The fine aggregates from three sources referred to as TS from the coastal region, QV from the North Rift and QB from Nairobi region were used during the study.

\subsubsection{Coarse Aggregates}

Coarse aggregate from four different regions of the country (Kenyan south coast region, the central region, the north rift region and the south rift region) were tested to determine their chemical composition. The same type of coarse aggregates from Mlolongo Quarry was then used to make the concrete for the compressive strength tests.

\subsubsection{Water}

Tap water from Jomo Kenyatta University of Agriculture and Technology water treatment plant was during the research. 


\subsection{Experimentation}

\subsubsection{Constituent Materials Characterization}

The cement and aggregates chemical elemental analysis was done using the Atomic Absorption spectrometer (AAS) in accordance to the EAS 148-2:2000I CS 91.100.10. East African Standard: Cements-Test Methods Part 2: Chemical Analysis. 2000. First Edition and following the procedures in Atomic Absorption Spectroscopy: Analytical Methods by Perkin Elmer and the results were confirmed through titration. The Initial setting time, compressive strength, flexural strength at 2, 7 and 28 days and density of the cements was based on BS EN196:2010 [32] [33] [34]. Cement fineness was tested based on the Blaine fineness apparatus for both the blended Portland cements and ordinary Portland cements. The tests were done at the Kenya Bureau of Standards Laboratories as shown in Figure 1.

The physical and mechanical properties tests on aggregates were done at the Jomo Kenyatta University of Agriculture and Technology (JKUAT) Civil Engineering laboratories. Sieve analysis was done on the aggregates based on BS EN 1097-6-2013; Bulk Density tested using (BS 812-2:1995), Specific gravity using (BS 812-102:1995), Water Absorption using (BS 813-2:1995) and Moisture Content suing (BS 812-109:1990).

\subsubsection{Concrete Mix Design and Compressive Strength Test}

Concrete mix design is the science of correct proportioning of concrete constituent materials based on structure requirements to obtain the desired properties of concrete such as strength and practical workability [6]. In Kenya, concrete mix design is done based on the British Standards.
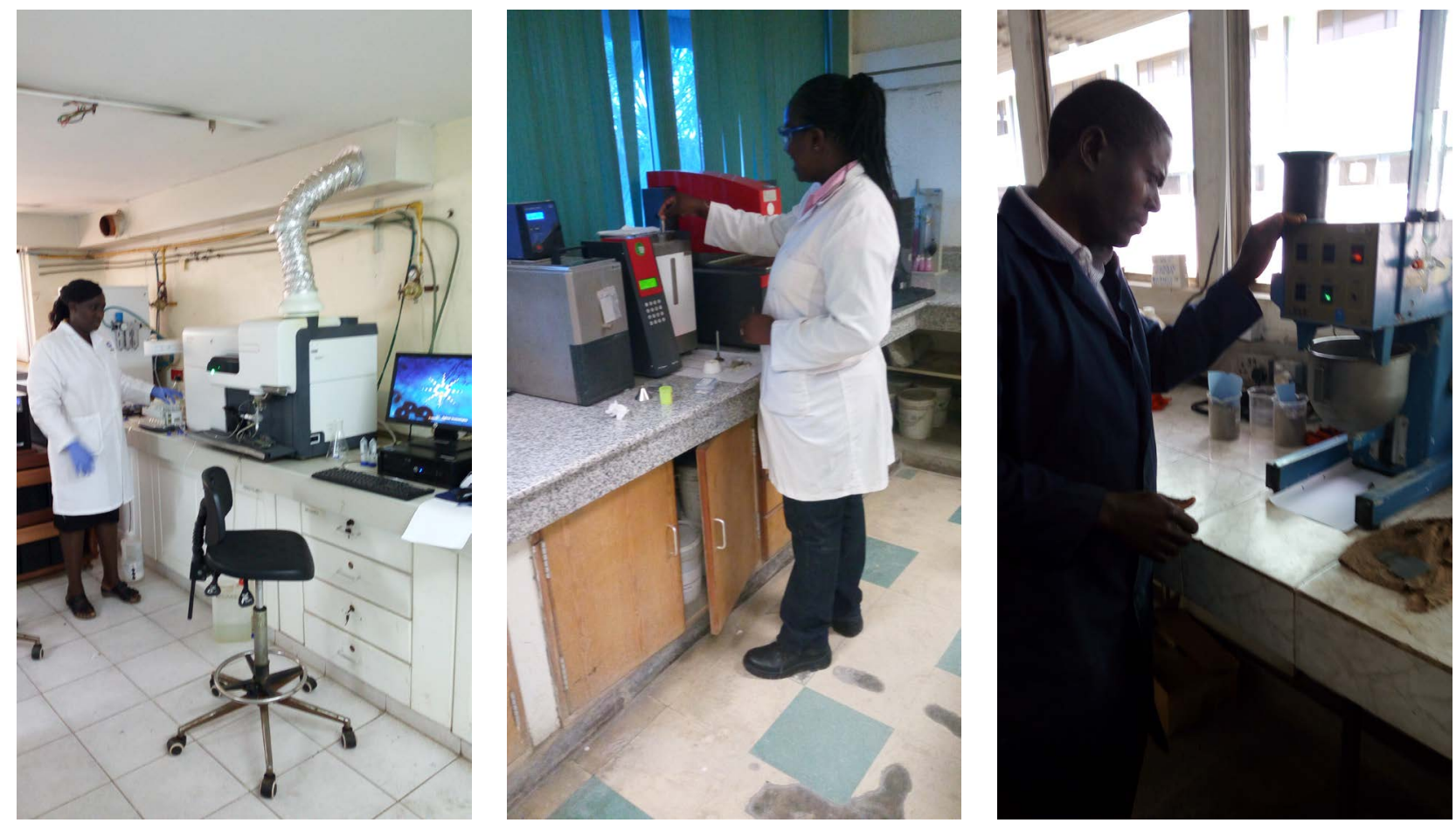

Figure 1. Atomic absorption spectrometer test, Blaine fineness and initial setting time test. 
The effect of the fine aggregates properties on the compressive strength of concrete was evaluated using the same concrete mix ratio of 1:1.5:3 for cement: sand: coarse aggregates to obtain concrete class $25 \mathrm{~N} / \mathrm{mm}^{2}$ at a constant slump of $50 \pm 5 \mathrm{~mm}$ using the three types of cements $(32.5 \mathrm{R}, 32.5 \mathrm{~N}$ and $42.5 \mathrm{~N})$ and fine aggregates from three locations (TS, QV and QB) while the effect of the cement type $(32.5 \mathrm{~N}$ and $42.5 \mathrm{~N})$ on the compressive strength of concrete was evaluated using five different classes of concrete (15 MPa, $20 \mathrm{MPa}, 25 \mathrm{MPa}, 30 \mathrm{MPa}$, and $35 \mathrm{MPa}$ ) designed using the British Standards based on same fine and coarse aggregates. The compressive strength of concrete was investigated at 7, 14 and 28 days using the Universal Testing Machine with a loading capacity of $1500 \mathrm{KN}$ in accordance to BS 1881-116: 1983.

\section{Results and Discussion}

\subsection{Properties of Locally Available Concrete Constituent Materials}

\subsubsection{Properties of Locally Available Cements}

\section{i) Chemical Properties of Cements in Kenya}

Cement is the most commonly used binder material in concrete. It makes concrete impermeable by filling up the voids existing in the aggregates and provides strength to the composite mix upon setting and hardening. The cements properties tested during this research were the chemical composition, the initial setting time, the compressive and flexural strengths and the density.

Three types of cements were investigated during the research and Tables 1-3 give the chemical properties of the different brands of the $32.5 \mathrm{~N}, 32,5 \mathrm{R}$ and $42.5 \mathrm{~N}$ cements respectively. The results in Figure 1 indicate that the different brands of $32.5 \mathrm{~N}$ cements in Kenya have varying chemical composition. The highest variations are in the amounts of $\mathrm{CaO}, \mathrm{SiO}_{2}$ and Insoluble Residue. CEM A has the highest amount of $\mathrm{CaO}(54.96 \%), \mathrm{CEM} \mathrm{F}$ having the highest $\mathrm{SiO}_{2}$ (39.54\%) and CEM D having the highest Insoluble residue (32.93\%).

Table 1. Chemical properties of different brands of $32.5 \mathrm{~N}$ blended cements in Kenya.

\begin{tabular}{cccccccccccc}
\hline CEM 32.5N & $\mathrm{CaO} \%$ & $\mathrm{SiO}_{2} \%$ & $\mathrm{SO}_{3} \%$ & $\mathrm{MgO} \%$ & $\mathrm{~K}_{2} \mathrm{O} \%$ & $\mathrm{Fe}_{2} \mathrm{O}_{3} \%$ & $\mathrm{Al}_{2} \mathrm{O}_{3} \%$ & $\mathrm{Na}_{2} \mathrm{O} \%$ & LOI \% & $\mathrm{CL} \%$ & IR \% \\
\hline CEM A & 54.96 & 37.28 & 0.97 & 1.48 & 1.51 & 1.51 & 3.86 & 0.43 & 2.97 & 0.01 & 28.34 \\
$\mathrm{CEM} \mathrm{D}$ & 50.08 & 39.24 & 0.95 & 0.96 & 1.42 & 1.64 & 3.49 & 0.23 & 2.96 & 0.03 & 32.93 \\
$\mathrm{CEM} \mathrm{F}$ & 52.78 & 39.54 & 0.95 & 0.75 & 0.96 & 1.47 & 2.44 & 0.45 & 3.33 & 0.02 & 32.57 \\
\hline
\end{tabular}

Table 2. Chemical properties of different brands of $32.5 \mathrm{R}$ blended cements in Kenya.

\begin{tabular}{cccccccccccc}
\hline CEM 32.5R & $\mathrm{CaO} \%$ & $\mathrm{SiO}_{2} \%$ & $\mathrm{SO}_{3} \%$ & $\mathrm{MgO} \%$ & $\mathrm{~K}_{2} \mathrm{O} \%$ & $\mathrm{Fe}_{2} \mathrm{O}_{3} \%$ & $\mathrm{Al}_{2} \mathrm{O}_{3} \%$ & $\mathrm{Na}_{2} \mathrm{O} \%$ & $\mathrm{LOI} \%$ & $\mathrm{CL} \%$ & $\mathrm{IR} \%$ \\
\hline CEM C & 52.39 & 40.39 & 0.97 & 1.22 & 1.22 & 1.36 & 3.12 & 0.35 & 2.97 & 0.01 & 28.34 \\
CEM D & 57.09 & 33.05 & 0.87 & 1.75 & 1.47 & 1.67 & 4.05 & 0.49 & 2.19 & 0.05 & 33.38 \\
CEM E & 52.49 & 28.94 & 2.09 & 1.25 & 1.10 & 1.92 & 4.14 & 0.10 & 4.12 & 0.02 & 12.11 \\
CEM F & 57.18 & 37.28 & 1.70 & 1.19 & 0.58 & 1.73 & 2.84 & 0.35 & 3.30 & 0.01 & 26.28 \\
\hline
\end{tabular}


Table 3. The chemical properties of different brands of $42.5 \mathrm{~N}$ cements in Kenya.

\begin{tabular}{cccccccccccc}
\hline CEM 42.5N & $\mathrm{CaO} \%$ & $\mathrm{SiO}_{2} \%$ & $\mathrm{SO}_{3} \%$ & $\mathrm{MgO} \%$ & $\mathrm{~K}_{2} \mathrm{O} \%$ & $\mathrm{Fe}_{2} \mathrm{O}_{3} \%$ & $\mathrm{Al}_{2} \mathrm{O}_{3} \%$ & $\mathrm{Na}_{2} \mathrm{O} \%$ & $\mathrm{LOI} \%$ & $\mathrm{CL} \%$ & $\mathrm{IR} \%$ \\
\hline CEM A & 61.78 & 20.01 & 1.09 & 0.90 & 1.09 & 2.06 & 4.26 & 0.10 & 3.60 & 0.02 & 1.15 \\
CEM B & 58.76 & 20.74 & 1.33 & 1.70 & 1.45 & 1.89 & 3.72 & 0.33 & 3.19 & 0.06 & 3.41 \\
CEM D & 60.86 & 22.31 & 1.03 & 1.73 & 1.37 & 1.89 & 4.44 & 0.21 & 3.62 & 0.01 & 3.12 \\
CEM E & 64.65 & 22.02 & 0.78 & 1.02 & 1.04 & 1.72 & 3.66 & 0.20 & 6.76 & 0.03 & 2.64 \\
CEM F & 63.84 & 22.67 & 1.31 & 1.24 & 1.28 & 1.80 & 4.12 & 0.07 & 2.61 & 0.02 & 4.60 \\
\hline
\end{tabular}

The properties of the 32.5R cements in Kenya are illustrated in Table 2. The different brands have varying properties with CEM $\mathrm{F}$ having the highest amount of $\mathrm{CaO}$ (57.18\%), CEM C having the highest $\mathrm{SiO}_{2}$ (40.39\%) and CEM C having the highest amount of Insoluble Residue (33.38\%). The chemical variations in $32.5 \mathrm{R}$ and $32.5 \mathrm{~N}$ can be attributed to the type and amounts of Pozzolanic materials used in the manufacture of the cements and the manufacturing process.

The results of the chemical analysis of the different brands of the locally available ordinary Portland cements $42.5 \mathrm{~N}$ are as illustrated in Table 3.

All the cement brands except CEM B met the minimum requirements of Portland cements as stated in ASTM C150 and KS EAS 18 - 1:2001 for CaO (60\% - 67\%), $\mathrm{SiO}_{2}(18 \%-25 \%), \mathrm{SO}_{3}(1 \%-3.5 \%), \mathrm{MgO}(0.1 \%-4 \%), \mathrm{K}_{2} \mathrm{O}(0.5 \%-$ $1 \%), \mathrm{Al}_{2} \mathrm{O}_{3}(3 \%-8 \%), \mathrm{Na}_{2} \mathrm{O}(0.5 \%-1 \%)$, LOI $(\leq 5 \%), \mathrm{IR}(\leq 5 \%)$ and $\mathrm{CL}$ $(\leq 0.10 \%)$. CEM B has $\mathrm{CaO} 58.76 \%$ which is less than $60 \%$ minimum requirement. The different brands however had varying properties which can be attributed to their manufacturing processes.

A comparison of the average chemical properties of the three types of cements illustrated in Figure 2 indicate that the blended Portland cements (32.5R and $32.5 \mathrm{~N}$ ) have Insoluble residues values of $25.03 \%$ and $31.28 \%$ on average respectively, much higher than that of the ordinary Portland cement which is $2.98 \%$. The amount of $\mathrm{CaO}$ in the blended cements (54.79\% and 52.61\%) was also much lower than that of the ordinary Portland cement $(61.98 \%)$. This is as a result of the Pozzolanic materials added to blended cements leading to a reduction in the $\mathrm{CaO}$ values. The blended Portland cements also had a higher percentage of $\mathrm{SiO}_{2}$ (38.69\% and 34.92\%) on average which are much higher than the maximum limit of $\geq 18 \%$ and $\leq 25 \%$ (ASTM) while the ordinary Portland cement have an average $\mathrm{SiO}_{2}$ of $21.55 \%$ which is within the recommended level. The difference in chemical composition of the various brands and types of cements are reflected in the difference in their mechanical properties and in the qualities of concrete produced by the different types of cements and thus it directly affects the compressive strength of concrete.

\section{ii) Compressive strength of Locally Available Cements}

The compressive strengths of cements from the six manufacturers were evaluated and the results show that other than CEM F 32.5R having $32.1 \mathrm{MPa}$ at 28 days, all the other cements met the minimum requirements of $32.5 \mathrm{MPa}-52.5$ $\mathrm{MPa}$ for the blended cements $(32.5 \mathrm{R}$ and $32.5 \mathrm{~N})$ and $42.5 \mathrm{MPa}-62.5 \mathrm{MPa}$ for 
the ordinary Portland cements $(42.5 \mathrm{~N})$ [31]. The different brands however had varying compressive strengths and for every brand, the blended Portland cements had lower compressive strength compared to the ordinary Portland cements as shown in Figure 3. On average, the 32.5R cements had the least compressive strength $(35.3 \mathrm{MPa})$ compared to $32.5 \mathrm{~N}$ cement with $(38.0 \mathrm{MPa})$ and $42.5 \mathrm{~N}$ cements $(45.5 \mathrm{MPa})$ at 28 days.

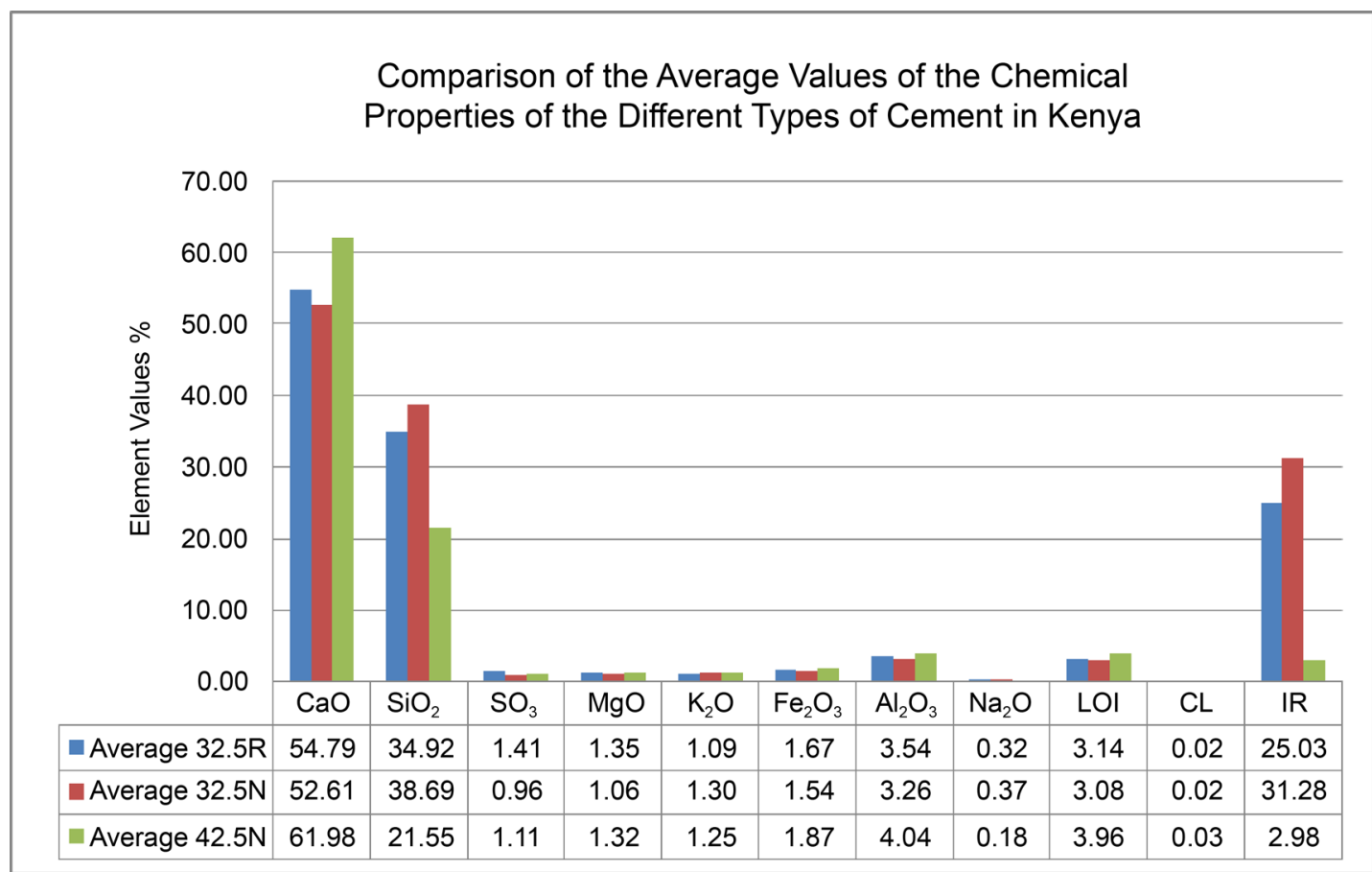

Figure 2. The chemical properties of different types cements in Kenya.

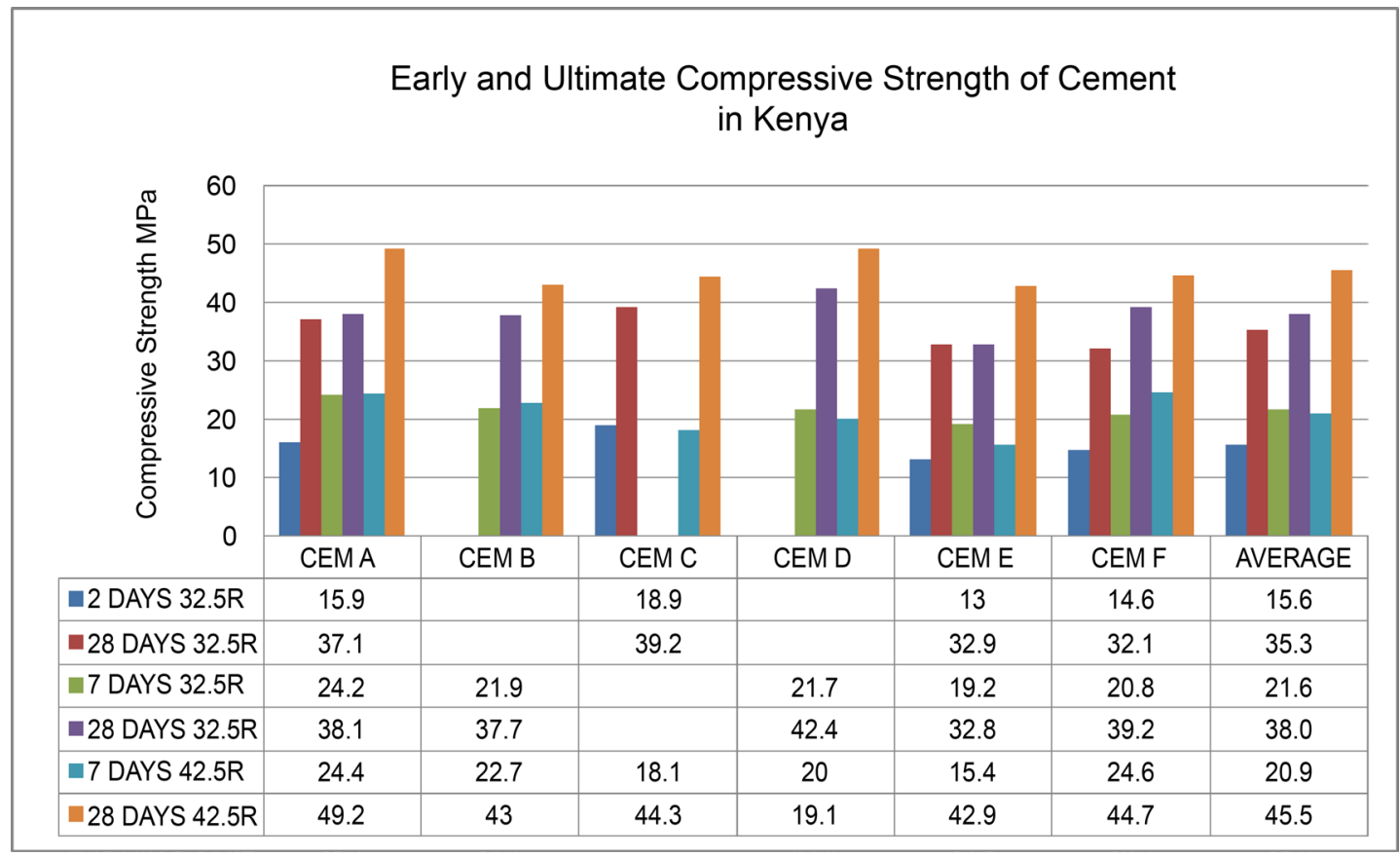

Figure 3. Early and ultimate compressive strength of cements in Kenya. 


\section{iii) Cement Flexural strength}

Figure 4 gives the results of the flexural strength of the different types and brands of cement in Kenya. At 28 days, the ordinary Portland cements had the highest value of flexural strength at $9.7 \mathrm{MPa}$ on average, followed by the $32.5 \mathrm{~N}$ cements with an average of $8.1 \mathrm{MPa}$ and the least was the $32.5 \mathrm{R}$ cements with an average of 6.4 MPa. The different cement brands however had varying flexural strengths for each cement type as indicated in Figure 6.

\section{iv) Consistency and Setting Time}

Setting time is affected by the cement composition, cement fineness, rate of hydration, and the ambient temperature. The results given in Figure 5 comparing the consistency and setting times of the different types and brands of cements indicate that the cements in Kenya have much higher values of initial setting time compared to the minimum required values. The limits for the blended Portland cements and ordinary Portland cements CEM 32.5 and CEM 42.5 is $\geq 60$ minutes while that of CEM 52.5 is $\geq 45$ minutes [32].

\section{v) Cement Density}

The different types of cements had varying densities. The $32.5 \mathrm{R}$ cement had an average density of $3117 \mathrm{~kg} / \mathrm{m}^{3}$ while the $32.5 \mathrm{~N}$ cements had an average density of $3114 \mathrm{~kg} / \mathrm{m}^{3}$ and the $42.5 \mathrm{~N}$ cements had an average density of $2995 \mathrm{~kg} / \mathrm{m}^{3}$.

\section{vi) Cement Fineness}

Cement fineness test results showed that the blended Portland cements are finer than the ordinary Portland cements for each brand tested as shown in Figure 6. Finer cements have higher surface areas therefore they react faster due to the exposed surface areas. The higher fineness of the blended Portland cements compared to the ordinary Portland cements is to increase their strength. It was

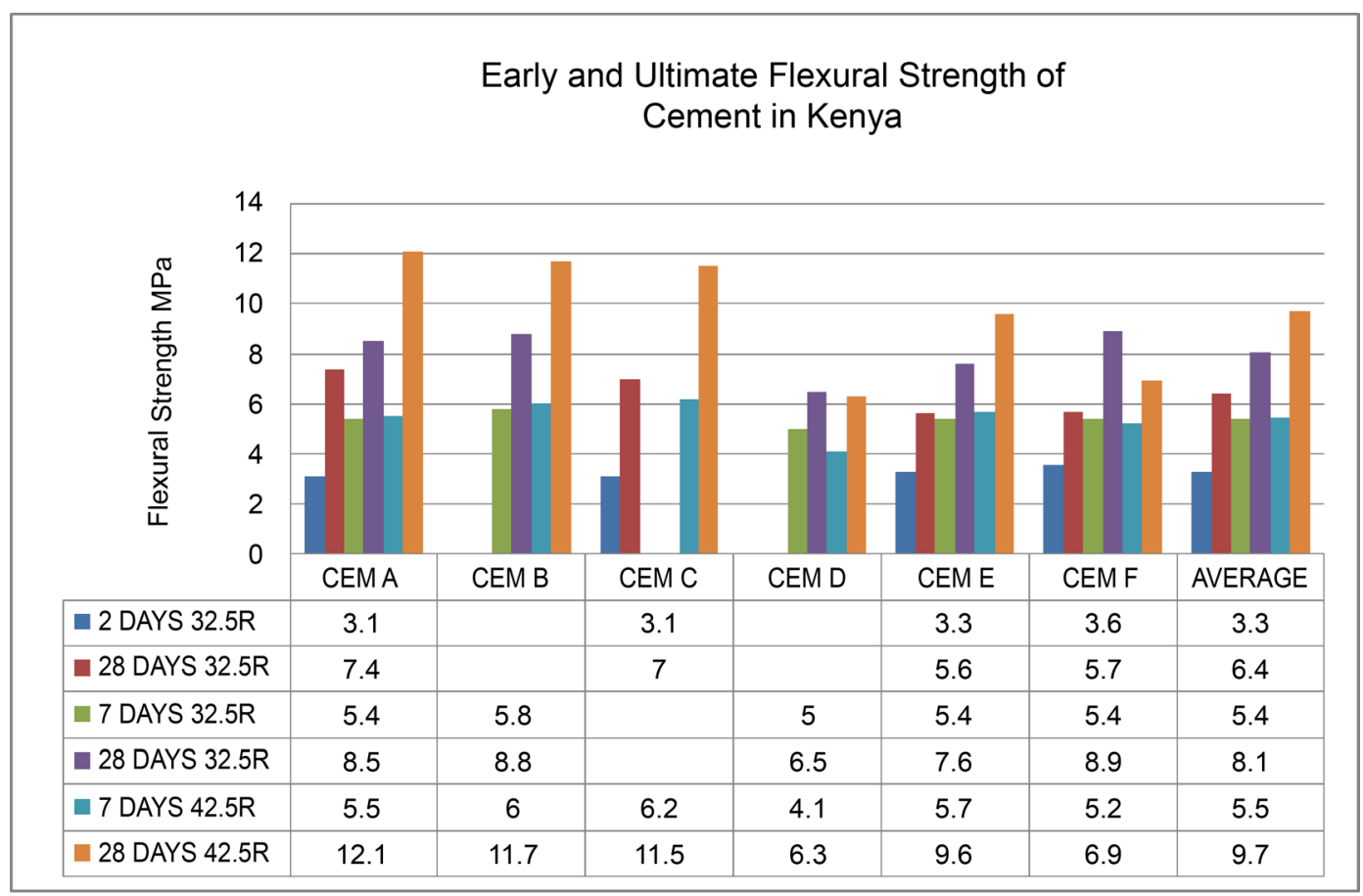

Figure 4. Early and ultimate flexural strength $\left(\mathrm{N} / \mathrm{mm}^{2}\right)$. 

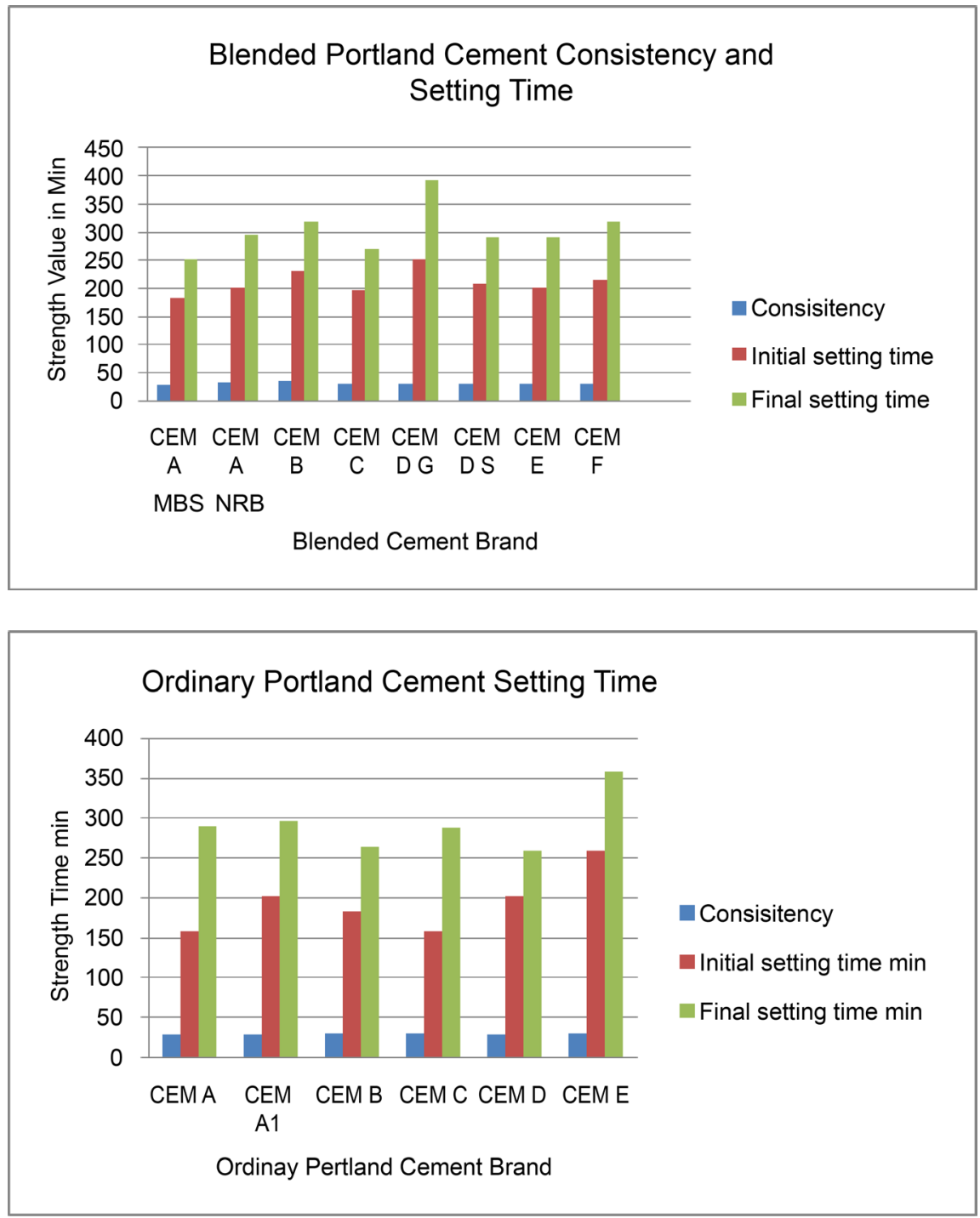

Figure 5. Initial setting time of different types of cements in Kenya (minutes).

however noted that for each type of cement, the different brands had varying fineness with CEM B having the highest Blaine fineness for both the ordinary and blended Portland cements as illustrated in Figure 6.

\subsubsection{Properties of Locally Available Aggregates}

The shape and texture of aggregate affects the properties of fresh concrete. Concrete is more workable when smooth and rounded aggregate is used instead of rough angular or elongated aggregate. The grading or size distribution of aggregate determines the paste requirement for workable concrete while the moisture content of the aggregates influences the water/binder ratio. The density of the aggregates is required in mixture proportioning to establish weight-volume relationships. Provided that aggregates are stronger than the paste and strong enough not to break down or abrade during the mixing process, crushing strength has no effect on the properties of fresh concrete.

\section{i) Properties of Coarse Aggregates}



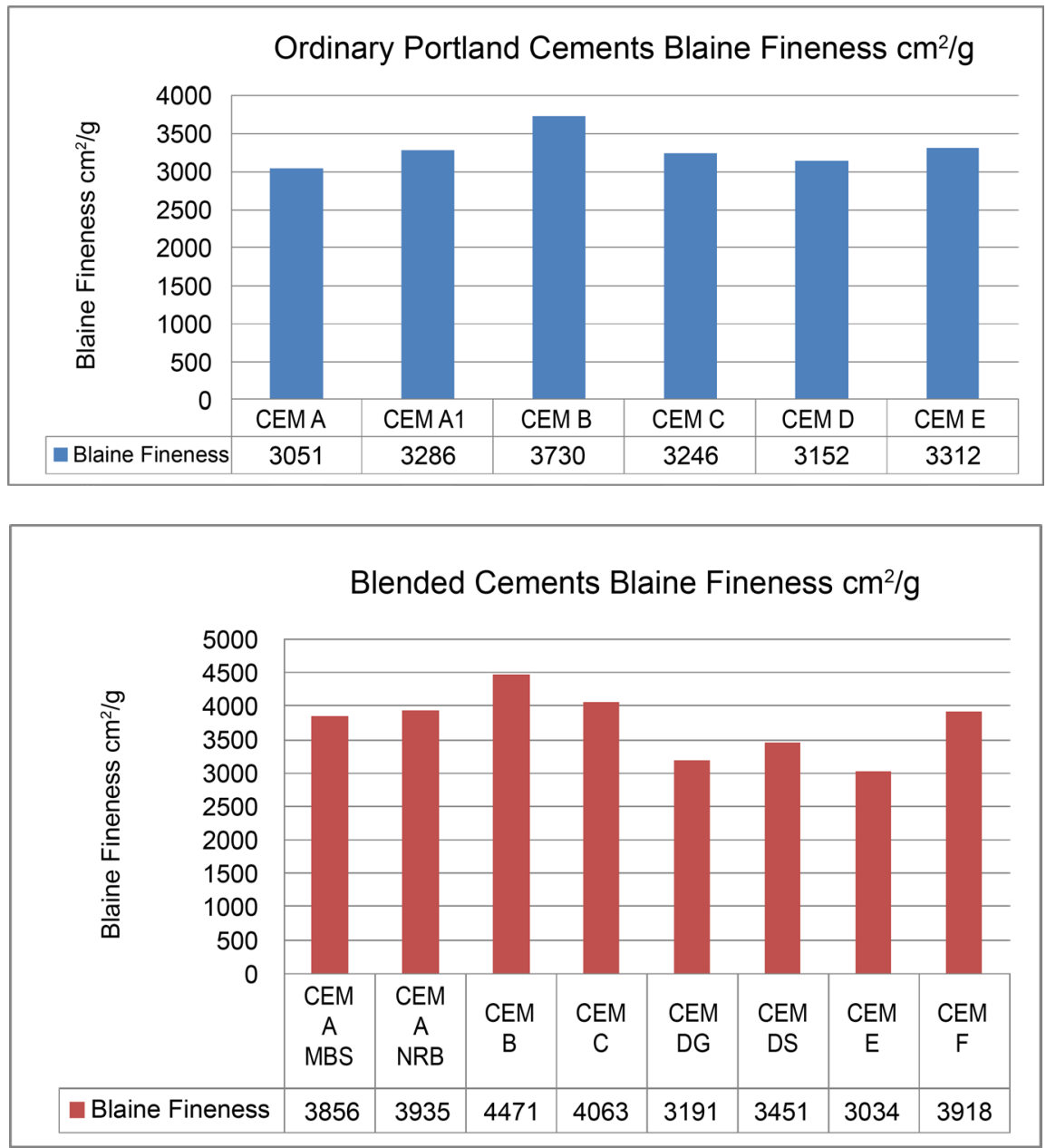

Figure 6. Blaine fineness of different types of cements in Kenya $\left(\mathrm{cm}^{2} / \mathrm{g}\right)$.

In Kenya, the most commonly used coarse aggregates are the crushed stones obtained from quarries spread across the country. During this research, aggregates from five regions in the country were tested to establish their chemical composition and the results are as shown in Figure 7.

The results of the chemical analysis in Figure 7 indicate that other than the aggregates from the coastal regions which had high amounts of $\mathrm{CaO}(22.41 \%$ and $26.21 \%)$ and lower amounts of insoluble residues (36.87\% and $34.58 \%$ ) compared to aggregates from the other parts of the country which had insoluble residues amounting to more than 55\%, the aggregates from all the other sources had similar chemical properties.

The mechanical properties of the mlolongo coarse aggregates used in the experiment were investigated and the results are as shown in Table 4.

\section{ii) Properties of Fine Aggregates}

Fine aggregates affect the workability and the surface finish of concrete. Table 5 shows the physical and mechanical properties of the different fine aggregates used during the experiment.

The British and the Indian Standards recommend a maximum of $4 \%$ of silt and clay content in fine aggregates for concrete productions. Based on these 


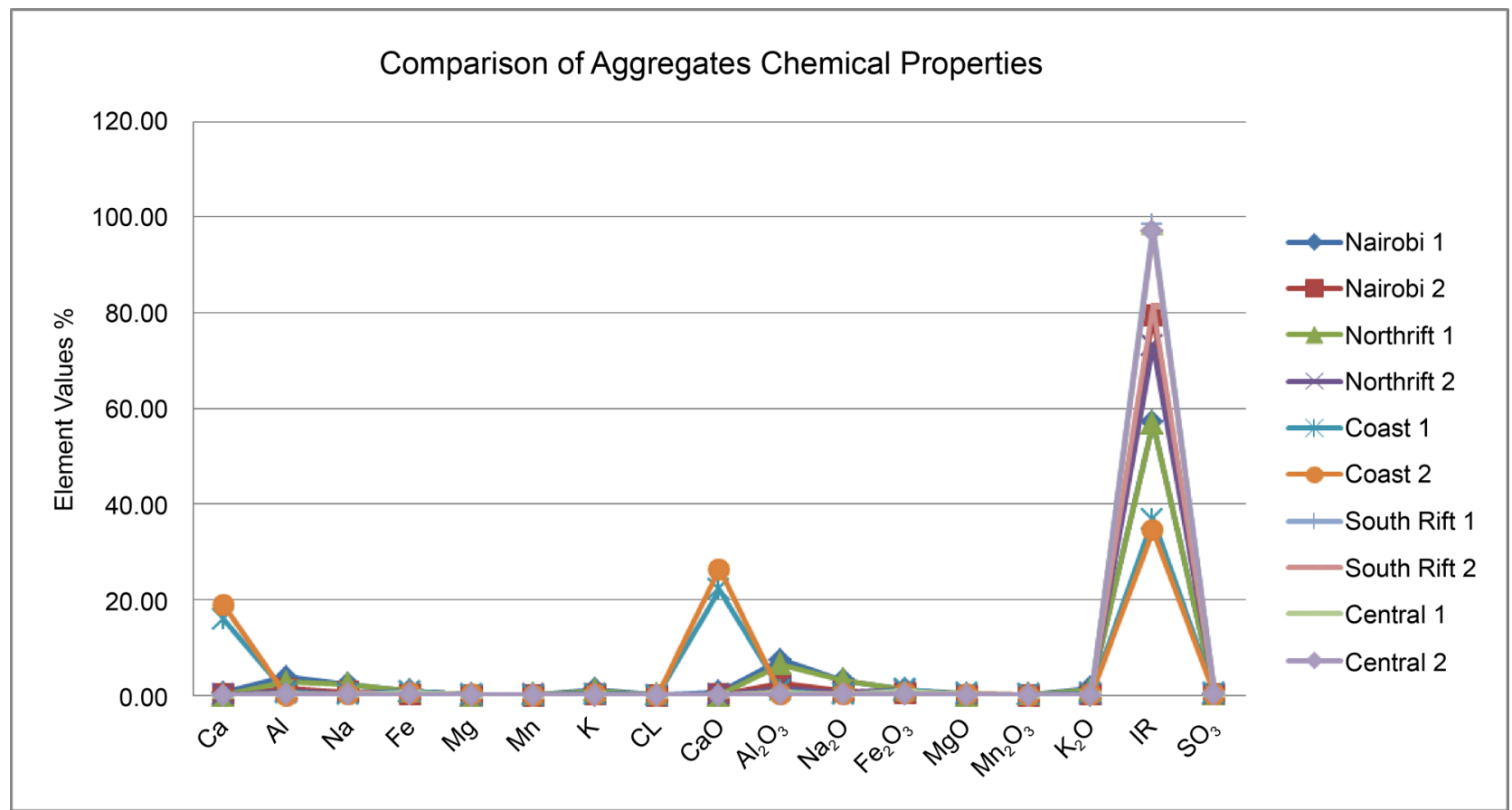

Figure 7. Comparison of aggregates chemical properties.

Table 4. Properties of coarse aggregates used during the experiment.

\begin{tabular}{ccccccc}
\hline Source & Bulk Density $\left(\mathrm{Kg} / \mathrm{m}^{3}\right)$ & Specific Gravity & ACV (\%) & AIV (\%) & Absorption & Fineness Modulus \\
\hline Mlolongo & 1447.917 & 2.5 & 22.27 & 12.06 & 1.25 & 3.62 \\
\hline
\end{tabular}

Table 5. Properties of fine aggregates.

\begin{tabular}{ccccccc}
\hline $\begin{array}{c}\text { Aggregate } \\
\text { Source }\end{array}$ & $\begin{array}{c}\text { Specific } \\
\text { Gravity }\end{array}$ & $\begin{array}{c}\text { Fineness } \\
\text { Modulus }\end{array}$ & $\begin{array}{c}\text { Water } \\
\text { Absorption }\end{array}$ & $\begin{array}{c}\text { Silt and } \\
\text { Clay Content }\end{array}$ & Surface Texture & $\begin{array}{c}\text { Particle } \\
\text { Shape }\end{array}$ \\
\hline Tiwi Sand (TS) & 2.83 & 3.014 & $7.825 \%$ & 5 & Smooth and Coarse & Rounded \\
Nairobi (QB) & 2.80 & 3.540 & $2.050 \%$ & 2.94 & Rough, angular with finer particles & Irregular \\
Naivasha (QV) & 2.31 & 2.587 & $1.32 . \%$ & 6.25 & Smooth and fine & Rounded \\
\hline
\end{tabular}

international standards, only one out of the three fine aggregates had silt contents within the recommended limit. Research has shown that fine aggregates from Nairobi and its environs have impurities that exceed the minimum recommended levels [8].

The sieve analysis results were as shown in Figure 8. The fine aggregates were falling under zones I and II based on the British Standards with percentage passing seive 600 micron being between $15 \%$ and $59 \%$.

\subsection{Influence of Cement Chemical Properties on Concrete Compressive Strength}

In concrete reaction, the main cement chemical properties responsible for the early and ultimate compressive strength development is $\mathrm{CaO}, \mathrm{SiO}_{2}, \mathrm{Al}_{2} \mathrm{O}_{3}$ and $\mathrm{Fe}_{2} \mathrm{O}_{3}$ required to form Silicates and Aluminates of Calcium such as the Tri-cal- 
cium silicate $\left(3 \mathrm{CaO} \cdot \mathrm{SiO}_{2}\right)$ and Di-calcium Silicate $\left(2 \mathrm{CaO} \cdot \mathrm{SiO}_{2}\right)$ which are responsible for the initial setting and early strength gain of the cements in concrete and the ultimate compressive strength development respectively. Iron Oxide reacts with Calcium and Aluminium to form the tricalcium aluminoferrite $\left(4 \mathrm{CaO} \cdot \mathrm{Al}_{2} \mathrm{O}_{3} \cdot \mathrm{Fe}_{2} \mathrm{O}_{3}\right.$ ) which imparts hardness and strength to the cement and consequently to the concrete.

The deficiency of $\mathrm{CaO}$ in the blended Portland cements shown in Figure 2 can explain the reduced compressive strengths of the blended cement concrete compared to the ordinary Portland cement concrete as indicated from the results in Figure 9. The blended Portland cement concrete therefore leads lower compressive strengths compared to the ordinary Portland cement concrete at 28 days

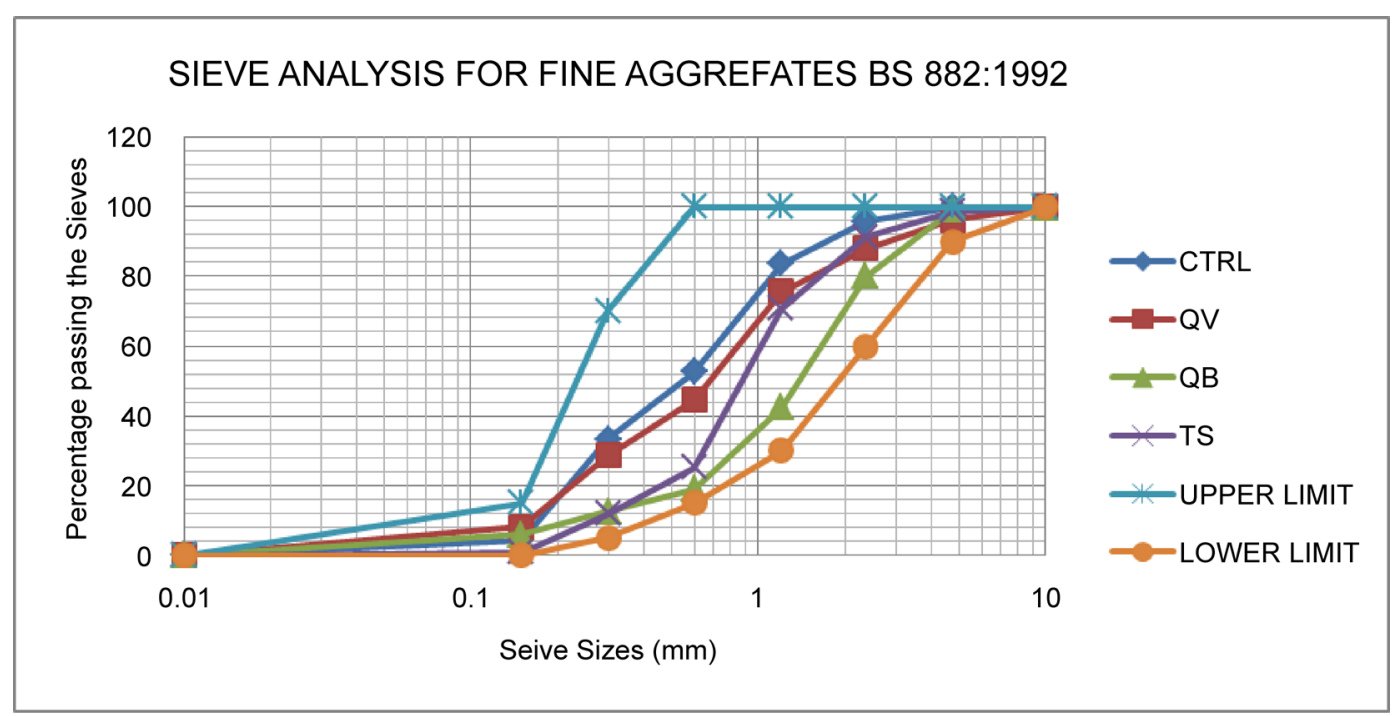

Figure 8. Sieve analysis results for the fine aggregates [2].

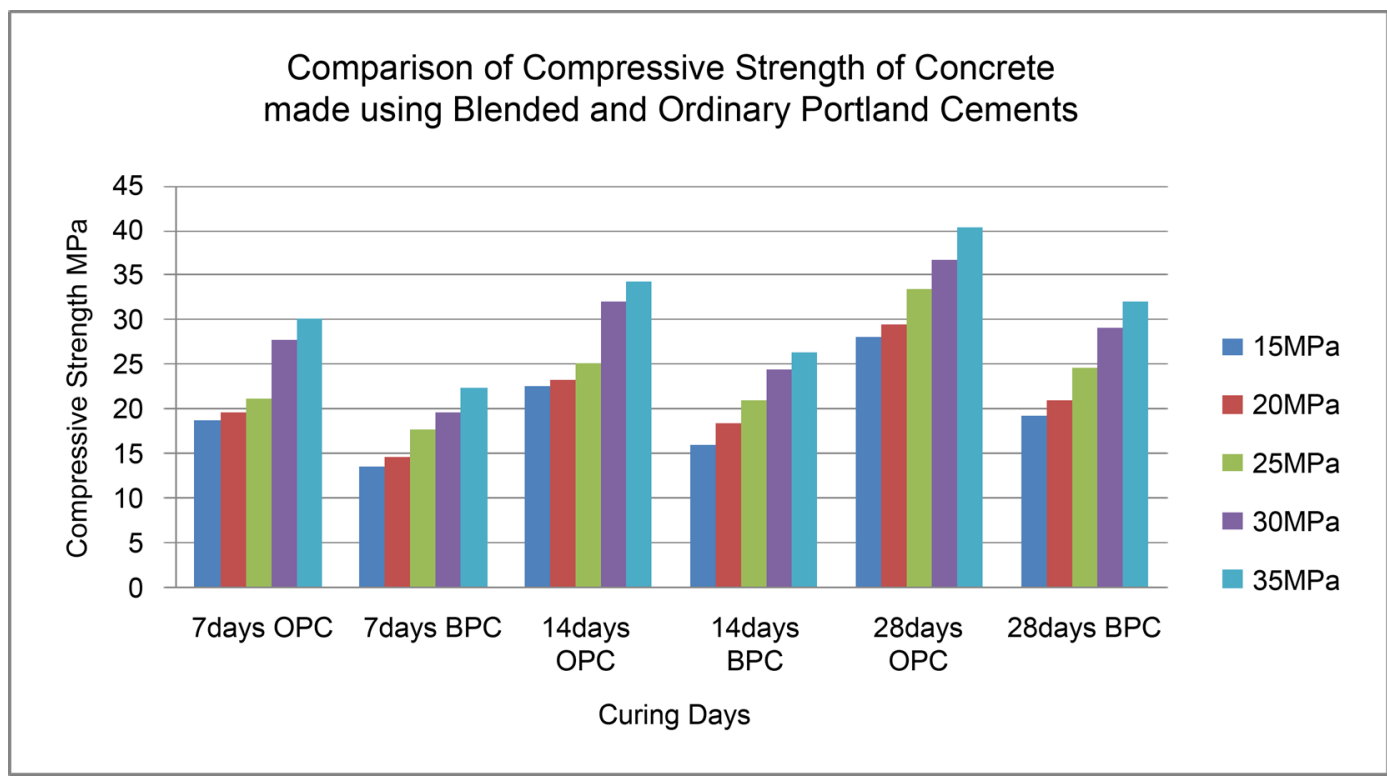

Figure 9. Comparison of compressive strength of blended cement concrete and ordinary Portland cement concrete. 
when the same mix design and aggregates are used. The most commonly used cement in Kenya and other developing countries is the blended Portland cements [1] [2] [12]. These cements are usually used to directly replace the ordinary Portland cements in the British DOE mix design method in Kenya leading to concrete which does not meet the target compressive strengths at 28 days as shown in Figure 9. This phenomenon can explain the poor quality of in situ concrete in Kenya produced by directly replacing the higher strength ordinary Portland cements with the cheaper and readily available blended Portland cements causing collapse of concrete buildings. The blended Portland cement concrete does not even get to the design strength of the structural concretes class $25 \mathrm{MPa}, 30 \mathrm{MPa}$ and $35 \mathrm{MPa}$ as shown in Figure 9.

The blended Portland cements have high amounts of Insoluble Residue which further lowers the compressive strength of the cements [13] [14].

\subsection{Influence of Cement Type on Concrete Compressive Strength}

The effect of the cement type on the compressive strength of concrete was investigated by using two types of cements $(42.5 \mathrm{~N}$ and $32.5 \mathrm{~N})$ to cast five different classes of concrete designed using the British DOE method and testing for compressive strength at 7, 14 and 28 days. The average results are as shown in Figure 8. This was then followed by investigating the effect of the different brands of the blended Portland cements on the compressive strength of concrete using the same mix design of 1:1.5:3 for class $25 \mathrm{MPa}$ concrete using the same aggregates. The results were as shown in Figure 10.

At 28 days, the average difference between the $32.5 \mathrm{~N}$ and the $42.5 \mathrm{~N}$ cements compressive strength is 7.5 MPa. When these two types of cements are used to cast concrete, the average difference in compressive strength of the concrete of

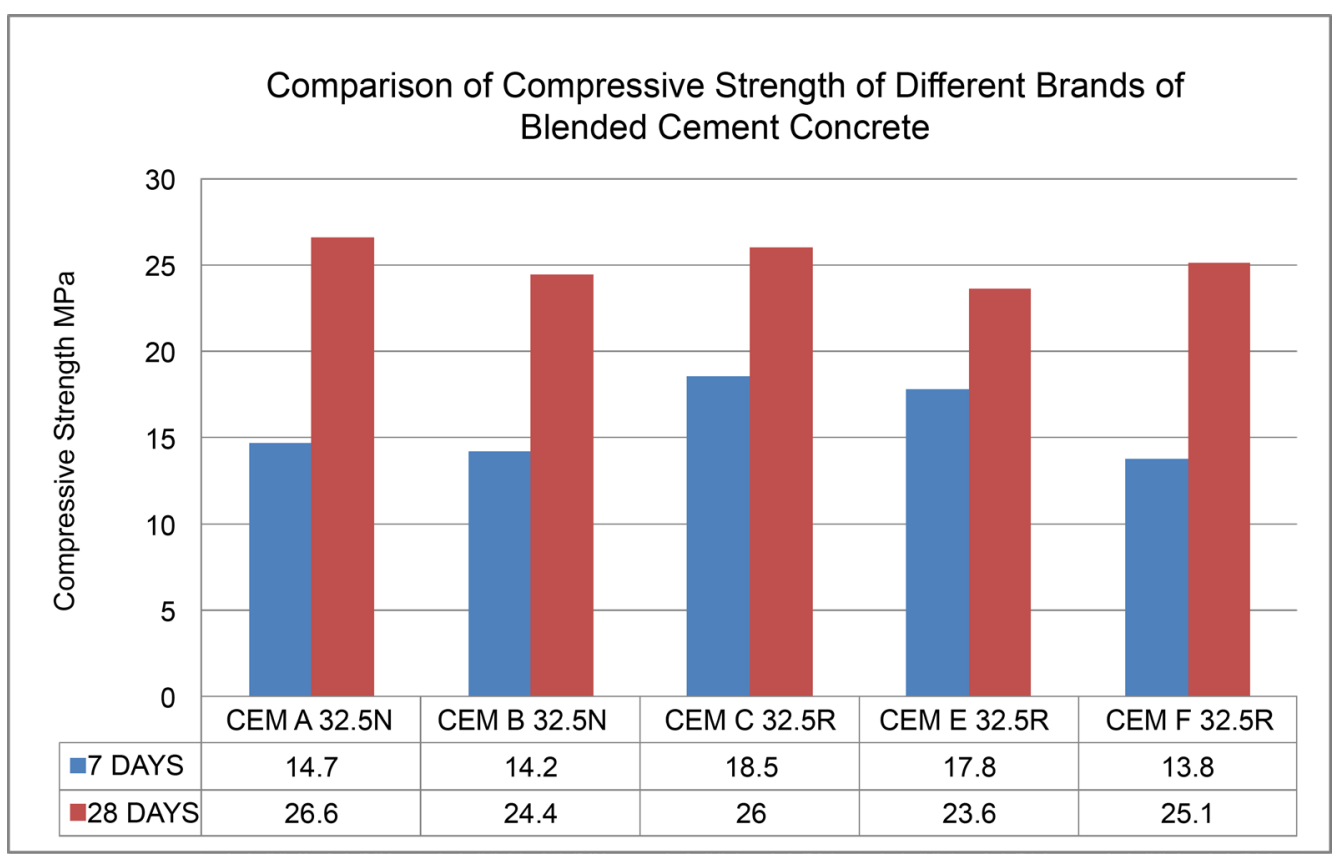

Figure 10. Compressive strength of concrete made using different brands of blended Portland cements. 
different strength classes is $8.35 \mathrm{MPa}$. This shows that the concrete compressive strength is directly proportional to the compressive strength of the cements used at 28 days. It is therefore necessary that different concrete mix proportions are used for the different types of cements to maximize on their properties. This is evident when the different types of cements are used to cast concrete using the same mix ratios whereby the blended Portland cement yielded lower concrete compressive strengths for all the strength classes designed for [2] [6] [12].

The performance of the different brands of blended Portland cements in Kenya was then evaluated and the results are as shown in Figure 10. The results show that the compressive strength of the cements is directly proportional to the compressive strength of concrete. Comparing the results in Figure 3 with those in Figure 9, it is clear the CEM A $32.5 \mathrm{~N}$ has resulted to the highest ultimate concrete compressive strength (26.6 MPa) as shown in Figure 10. This is followed by CEM C 32.5R (26 MPa), CEM F 32.5R (25.1 MPa), CEM B 32.5N (24.4 $\mathrm{MPa}$ ) and the least is CEM E $32.5 \mathrm{R}(23.6 \mathrm{MPa})$. The same order is seen in the ultimate compressive strength of the cements where for $32.5 \mathrm{~N}$ cements, CEM A has the highest ultimate compressive strength (38.1 MPa), while for the $32.5 \mathrm{R}$ cements, CEM C has the highest ultimate compressive strength (39.2 MPa). In all the cases however, at a mix ratio of 1:1.5:3, none of the cements achieved the target concrete strength at 28 days irrespective of the fact that the cements met the minimum compressive strength requirements and that the experiment was done within controlled workmanship conditions. This shows that the mix design ratio used was not appropriate for the cements and that its usage leads to poor quality concrete when the blended Portland cements are used thus possibly causing collapse of the concrete buildings in Kenya.

\subsection{Influence of Fine Aggregates Properties on the Water/Cement Ratio of Concrete}

The influence of the fine aggregates properties in Table 5 on the water/cement ratio was evaluated by maintaining a slump of $50 \pm 5 \mathrm{~mm}$. It was observed that the fine aggregates with finer particles required more water to wet their larger surface area, whilst the irregular shape and rougher texture of the angular aggregate demand more water than rounded aggregates as shown in Table 6. The fine aggregate TS which were Spherical, well rounded with smooth surface had shown an increase in workability with less water requirements to attain the required $50 \pm 5 \mathrm{~mm}$ slump. Fine aggregate $\mathrm{QB}$ which were angular, elongated, rough surfaced with fine particles and Fine aggregate QV with finer particles required more in order to achieve a constant slump of $50 \pm 5 \mathrm{~mm}$ [24] [25] [30].

\subsection{Effect of Fine Aggregates Properties on the Compressive Strength of Concrete}

The effect of the different fine aggregates types on the compressive strength of concrete was evaluated by casting cubes and testing at 7 and 28 days the compressive strength of the concrete. The same (Mlolongo) coarse aggregates were 
used at the same mix ratio of 1:1.5:3 at a constant slump of $50 \pm 5 \mathrm{~mm}$. It was observed that fine aggregate (TS) from the coastal region yielded a higher strength compared to the other fine aggregates QB and QV as shown in Figure 11.

The results show that the strength development of concrete does not only depend on the grading of the fine aggregates but also on the shape and texture of the fine aggregates whereby the coastal fine aggregates had were smooth, coarse and rounded thus required less water to achieve the required slump thus reducing the water/cement ratio and in turn increasing the compressive strength of concrete with all the three different types of cements used. QV had finer particles which required more water to wet their large surface area at a constant slump, thus decreased its strength while QB had irregular shape and rougher texture with finer particles which demanded more water to achieve the required

Table 6. Influence of fine aggregates on water/cement ratio of concrete mix.

\begin{tabular}{|c|c|c|c|c|}
\hline Mix NO & Cement Type & Fine Aggregate & W/C Ratio & Slump $(50 \pm 5 \mathrm{~mm})$ \\
\hline \multirow{3}{*}{ MIX1 } & \multirow{3}{*}{ CEMA 42.5N } & TS & 0.55 & 46 \\
\hline & & QB & 0.65 & 46 \\
\hline & & QV & 0.60 & 45 \\
\hline \multirow{3}{*}{ MIX2 } & \multirow{3}{*}{ CEMA $32.5 \mathrm{~N}$} & TS & 0.40 & 45 \\
\hline & & QB & 0.67 & 45 \\
\hline & & QV & 0.64 & 54 \\
\hline \multirow{3}{*}{ MIX3 } & \multirow{3}{*}{ CEMB 32.5R } & TS & 0.40 & 46 \\
\hline & & QB & 0.65 & 45 \\
\hline & & QV & 0.60 & 46 \\
\hline
\end{tabular}

Compressive Strength of Concrete Using Different Fine Aggregates

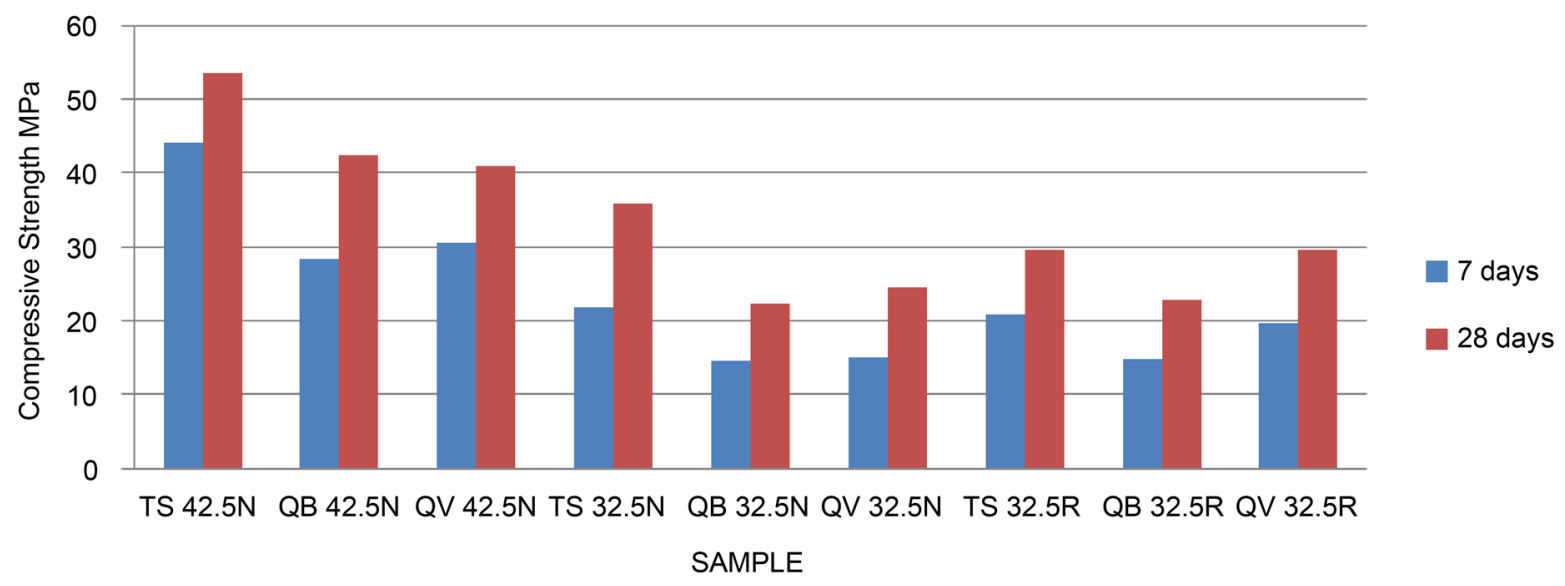

Figure 11. Strength development for $42.5 \mathrm{~N}, 32.5 \mathrm{~N}$ and $32.5 \mathrm{R}$ using different fine aggregates [2]. 
slump, thus reducing the concrete compressive strength. The concrete made using QB fine aggregates and 32.5N blended Portland cement had the lowest compressive strength since it required the highest amount of water as shown in Table 6 ( 0.67 water/cement ratio) to achieve the target slump of $50 \pm 5 \mathrm{~mm}$ therefore lowering the overall concrete strength as shown in Figure 11.

Research has shown that $86.2 \%$ of sand in Nairobi and its environs have silt content that exceed the minimum recommended limits for silt and clay content [8]. Two of the three types of fine aggregates used in this research exceeded the minimum limit of $4 \%$ stated in the British Standards. This therefore shows that majority of the fine aggregates used in the construction sites exceed the minimum requirements thus they reduce the compressive strength of concrete in the country leading to possible failure of concrete buildings.

\section{Conclusions}

The compressive strength of concrete depends on the chemical and the mechanical properties of the ingredients used and concrete mix proportions among other factors. From the results of this experimental investigation, on average, the cements tested met the minimum compressive strength requirements. The different cement brands however had varying chemical, physical and mechanical properties. As expected, the ordinary Portland cements had higher strengths compared to the blended Portland cements and when the different cement types were used to cast concrete designed based on the commonly used British Standards, the blended Portland cement concrete did not meet the target compressive strengths at 28 days while the ordinary Portland cement concrete exceeded the target strength when the same mix design was used. It is therefore evident that the currently used concrete mix design procedures yield concrete that does not meet the target ultimate compressive strength requirements at 28 days when blended Portland cements are used to directly replace the ordinary Portland cements, which is the current practice in Kenya possibly leading to failure of concrete structures in Kenya.

It was further observed fine aggregates from the coastal region (TIWI) required less water to achieve the target slump reducing the water/cement ratio of the mix and leading to increased concrete compressive strengths when all the three types of cements were used. Only one out of the three fine aggregate types used during the experiment met the minimum requirements for clay and silt content further reduced the compressive strength of the in situ concrete in Kenya.

The Kenyan construction professionals should therefore come up with policies to ensure quality control of construction materials and develop a mix design method for the cheaper and commonly used blended Portland cements to ascertain the quality of in situ concrete in the country to save lives and property lost due to the collapse of concrete structures.

\section{Acknowledgements}

The authors wish to thank Pan African University for the research funds, the 
Kenya Bureau of Standards Testing department and Jomo Kenyatta University of Agriculture and Technology for the laboratory equipment's and technical staff used during the research.

\section{References}

[1] Koteng, D.O. (2013) Concrete Use for Sustainable Development. The 20th Engineers International Conference, Kisumu, 8-10 May 2013, 1-19.

[2] Okumu, V.A., Oyawa, W.O. and Shitote, S.M. (2016) The Effect of the Properties of Constituent Materials on the Quality of Concrete in Kenya. Proceedings of the 2016 Annual Conference on Sustainable Research and Innovation, Nairobi, 4-6 May 2016, 225-230.

[3] Shaibu, R.A., Mutuku, R.N. and Nyomboi, T. (2014) Strength Properties of Sugarcane Bagasse Ash Laterised Concrete. International Journal of Civil and Environmetal Research, 1, 110-121.

[4] Lynne, L. (2005) Concrete Vaulted Construction in Imperial Rome Innovations in Context. Cambridge University Press, London.

[5] Wegian, F.M. (2010) Effects of Seawater for Mixing and Curing on Structural Concrete. The IES Journal Part A: Civil \& Structural Engineering, 3, 235-243.

[6] Kumbhar, P.D. and Murnal, P.B. (2012) Assessment of Suitability of Existing Mix Design Methods of Normal Concrete for Designing High Performance Concrete. International Journal of Civil and Structural Engineering, 3, 158-167.

[7] Marthoga, C. (2015) Effects of PET Fibre Arrangement and Dimensions on Mechanical Properties of Concrete. The IES Journal Part A: Civil \& Structural Engineering, 8, 111-120.

[8] Ngugi, H.N., Mutuku, R.N. and Gariy, Z.A. (2014) Effects of Sand Quality on Compressive Strength of Concrete: A Case of Nairobi County and Its Environs, Kenya. Open Journal of Civil Engineering, 4, 255-273. https://doi.org/10.4236/ojce.2014.43022

[9] Maciulaitis, R., Vaiciene, M. and Zurauskiene, R. (2009) The Effects of Concrete Composition and Aggregates Properties on Performance of Concrete. Journal of Civil Engineering and Management, 15, 317-324. https://doi.org/10.3846/1392-3730.2009.15.317-324

[10] Ahmad, S. (2007) Optimum Concrete Mixture Design Using Locally Available Ingredients. The Arabian Journal of Science and Engineering, 31, 27-33.

[11] Oyawa, W.O., Githimba, N.K and Mang'urio, G.N. (2016) Structural Response of Composite Concrete Filled Plastic Tubes in Compression. Steel and Composite Structures, 21, 589-604.

[12] Adewole, K.K., Ajagbe, W.O. and Arasi, I.A. (2015) Determination of Appropriate Mix Ratios for Concrete Grades Using Nigerian Cements. Leonardo Electronic Journal of Practices and Technologies, 26, 79-88.

[13] Kiattikomol, K., Jaturapitakkul, C. and Tangpagasit, J. (2000) Effect of Insoluble Residue on Properties of Portland Cement. Cement and Concrete Research, 30, 1209 1214. https://doi.org/10.1016/S0008-8846(00)00315-X

[14] Mohamed, M.J. (2013) Effect of Curing Method and Insoluble Residue in Cement on the Compressive Strength of Portland Cement Mortar. Al-Qadisiya Journal for Engineering Sciences, 6, 74-80.

[15] Dhir, R.K., Limbachiya, M.C., Mc Carthy, M.J. and Chaipanic, A. (2007) Evaluation of Portland Limestone Cements for Use in Concrete Construction. Materials and 
Structures, 40, 459-473. https://doi.org/10.1617/s11527-006-9143-7

[16] Ghrici, M., Kenai, S. and Meziane, E. (2006) Mechanical and Durability Properties of Cement Mortar with Algerian Natural Pozzolana. Journal of Materials Science, 41, 6965-6972. https://doi.org/10.1007/s10853-006-0227-0

[17] Muller, C. (2012), Use of Cement in Concrete According to European Standard EN 206-1. Housing and Building National Research Center HBRC Journal, 8, 1-7. https://doi.org/10.1016/j.hbrcj.2012.08.001

[18] Alp, I., Deveci, H., Sungun, Y.H., Yilmaz, A.O., Kesimal, A. and Yilmaz, E. (2009) Pozzolanic Charracteristic of Natural Raw Material for Use in Blended Cements. Iranian Journal of Science and Technology. Transaction B, Engineering, 33, 291 300.

[19] Mouli, M. and Khelafi, H. (2008) Performance Characteristics of Lightweight Aggregate Concrete Containing Natural Pozzolan. Building and Environment, 43, 31 36. https://doi.org/10.1016/j.buildenv.2006.11.038

[20] Marar, K. and Eren, Ö. (2011) Effect of Cement Content and Water/Cement Ratio on Fresh Concrete Properties without Admixtures. International Journal of the Physical Sciences, 6, 5752-5765.

[21] Muhit, I.B., Haque, S. and Alam, M.R (2013) Influence of Crushed Coarse Aggregates on Properties of Concrete. American Journal of Civil Engineering and Architecture, 1, 103-106. https://doi.org/10.12691/ajcea-1-5-3

[22] Bustnes, H.M., Lagerblad, B. and Forssberg, E. (2004) The Function of Fillers in Concrete. Materials and Structures, 37, 74-81. https://doi.org/10.1617/13694

[23] Lijuan, K. and Yuanbo, D. (2015) Interfacial Interaction of Aggregate-Cement Paste in Concrete. Journal of Wuhan University of Technology-Material Science Edition, 30, 117-121.

[24] Gong, C., Zhang, J., Wang, S. and Lu, L. (2015) Effect of Aggregate Gradation with Fuller Distribution on Properties of Sulpho aluminate Cement Concrete. Journal of Wuhan University of Technology_Material Science Edition, 30, 1029-1035.

[25] Chi, J.M., Huang, R., Yang, C.C. and Chang, J.J. (2003) Effect of Aggregate Properties on the Strength and Stiffness of Lightweight Concrete. Cement and Concrete Composites, 25, 197-205. https://doi.org/10.1016/S0958-9465(02)00020-3

[26] Donza, H., Cabrera, O. and Irassar, E.F. (2002) High Strength Concrete with Different Fine Aggregates. Cement and Concrete Research, 32, 1755-1761. https://doi.org/10.1016/S0008-8846(02)00860-8

[27] Ke-Ru, W., Chen, B., Yao, W. and Zhang, D. (2001) Effect of Coarse Aggregates Type on Mechanical Properties of High Performance Concrete. Cement and Concrete Research, 31, 1421-1425. https://doi.org/10.1016/S0008-8846(01)00588-9

[28] Ozturan, T. and Cecen, C. (1997) Effect of Coarse Aggregate Type on Mechanical Properties of Concrete with Different Strengths. Cement and Concrete Research, 27, 165-170. https://doi.org/10.1016/S0008-8846(97)00006-9

[29] Meddah, M.S., Zitouni, S. and Belaabes, S. (2010) Effect of Content and Particle Size Distribution of Coarse Aggregate on the Compressive Strength of Concrete. Construction and Building Materials, 24, 505-512. https://doi.org/10.1016/j.conbuildmat.2009.10.009

[30] Katz, A. and Baum, H. (2006) Effect of High Levels of Fines Content on Concrete Properties. ACI Materials Journal. Technical Paper, 103, 476-482.

[31] Kenya Bureau of Standards (2005) KS EAS 18-1:2001-Cement Part 1: Composition, Specification and Conformity Criteria for Common Cements. Kenya Bureau of Standards, Nairobi. 
[32] Ahmad, S. and Alghamdi, S.A. (2014) A Statistical Approach to Optimizing Concrete Mixture Design. The Scientific World Journal, 2014, Article ID: 561539.

[33] Kenya Bureau of Standards (2000) EAS 148-2: 2000 ICS 91.100.10. East African Standards. Cements-Test Methods. Part 2. Chemical Analysis. Kenya Bureau of Standards, Nairobi.

[34] Elmer, P. (1996) Atomic Absorption Spectroscopy: Analytical Methods. The Perkin Elmer Corporation, Waltham.

Submit or recommend next manuscript to SCIRP and we will provide best service for you:

Accepting pre-submission inquiries through Email, Facebook, LinkedIn, Twitter, etc. A wide selection of journals (inclusive of 9 subjects, more than 200 journals)

Providing 24-hour high-quality service

User-friendly online submission system

Fair and swift peer-review system

Efficient typesetting and proofreading procedure

Display of the result of downloads and visits, as well as the number of cited articles Maximum dissemination of your research work

Submit your manuscript at: http://papersubmission.scirp.org/

Or contact ojce@scirp.org 